\title{
Profits From Currency Futures Based On The Random Walk Hypothesis
}

Allen B. Atkins, (E-mail: Allen.Atkins@nau.edu), Northern Arizona University Somnath Basu, (E-mail: basu@clunet.edu), California Lutheran University

\begin{abstract}
Since the advent of floating exchange rates in 1973 there has been a debate about what is the best predictor of currency spot rates. The two most prominent candidates have been the current futures price and the current spot price. Lee Thomas' $(1985,1986)$ basic proposition rests on the argument that if the current spot rate follows a driftless random-walk process, then the spot rate of a currency will not tend toward the rate of the futures contract price. In other words, the best predictor of the spot rate in the future is today's spot price and not today's futures contract price. The investing strategy indicated by this belief is to simply buy (go long) any futures contract that is below today's spot price and sell (go short) any contract that is above today's spot price. Results from January of 1990 through March of 2003 show that by following this strategy, 63.2\% of the trades result in a profit. Various simulations result in annualized returns from 5.18\% to $14.76 \%$ and none results in a margin call.
\end{abstract}

\section{INTRODUCTION}

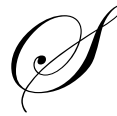

ince the advent of floating exchange rates in 1973 there has been a debate about what is the best predictor of currency spot rates. The two most prominent candidates have been the current futures price and the current spot price. An excellent summary of early research done on this subject is presented in Hodrick (1987). The current futures price is set by arbitrage conditions relating to the current interest rates in the two countries. For example, if the one-year interest rate in the U.S. is 5\% and the one-year interest rate in Japan is $2 \%$ then the one-year futures price for the dollar will be trading at a $3 \%$ discount to today's spot price. If this were not true an arbitrage could easily be constructed to profit from the discrepancy. ${ }^{1}$ The spot price, however, does not always end at the rate predicted by the futures price. In fact the current spot price, which is set by supply and demand in the current market, seems to be at least as good a predictor of next period's spot price as today's futures price. This suggests a simple trading rule. An investor should simply buy (go long) any futures contract that is below today's spot price and sell (go short) any contract that is above today's spot price. In effect, an investor should always trade as if the spot will end the period at today's spot rate and bet that movements toward the futures price will not occur. Lee Thomas $(1985,1986)$ demonstrated that even this naïve strategy can produce significant profits. ${ }^{2}$

Thomas' basic proposition rests on the argument that if the current spot rate follows a driftless random-walk process, then the future spot rate will not tend toward the futures rate set in today's market. Today's spot price will follow a random-walk process if all the information that is currently known about a particular currency is quickly incorporated in the current spot rate. Thomas goes on to show that if this is true, then an opportunity exists to earn a

\footnotetext{
${ }^{1}$ For example, assume the U.S. rate is $5 \%$ and the Japanese rate is $2 \%$. Also assume that today's spot price is 100 Yen per dollar and the oneyear futures price is 96 Yen per dollar. This discount is about $4 \%$ instead of the $3 \%$ that would be required for no arbitrage. An arbitrager could take $\$ 1$ million and buy 100 million Yen, invest them at $2 \%$ to end the year with 102 million Yen. He could then convert back to dollars at the futures price of $96 \mathrm{Yen} / \$$ and have $\$ 1.0625$ million dollars. This is far better than the $\$ 1.05$ million he would have received if he had invested his dollars in the U.S, at $5.0 \%$.

${ }^{2}$ For an early discussion of filter rules used in trading foreign currencies, see Alexander (1961), Dooley and Shafer (1983), and Sweeney (1986) among others.
} 
speculative positive return. His work includes observations from the spot and futures currencies markets from 19741983.

Currency futures were just beginning to be widely used during the time period considered in Thomas' study. Since then, one could argue, the currency markets have become considerably more informationally efficient due both to technological advances and to the large increase in the volume of trading in these markets. Thus, if the spot rate followed a random walk during the time period studied by Thomas, then today this process may have strengthened. If speculative abnormal returns were possible during the earlier time, they should not only be possible today but perhaps greater.

On the other hand, it is often axiomatic in the field of finance that any strategy that produces an above normal risk-adjusted return should disappear as soon as it is discovered and known by the financial markets. One could, therefore, argue that the naïve strategy could no longer be effective.

There are several possible outcomes. First, the large returns shown by Thomas may have disappeared or significantly decreased showing that the discovery of this strategy has caused it to disappear. Second, the returns may have increased due to an increase in the "efficiency" of the currency markets. Third, the returns may have continued at about the same level and simply indicate a return appropriate to the risk being taken in the strategy.

In the remainder of the paper these issues will be examined. In section I the data are described. In section II the basic results of the trading strategy are discussed and in section III results from some simulations are shown. Section IV compares our results to those of Thomas and the conclusions are presented in section V.

\section{THE DATA}

Futures prices for the first day of each quarter are collected from the Wall Street Journal for 7 major currencies, from January of 1990 through March of 2003. These currencies are the Australian dollar (AUD), the Canadian dollar (CAD), the Swiss Franc (SF), the British Pound (Pound), the Japanese Yen (Yen), the German Mark (DM) and the Euro. Spot prices are collected for the first day of each quarter and the Friday before each contract expires (or the closest day if Friday is a holiday). We chose the Friday before the contract expires to avoid any unusual price movements during the last several days of the contract period. These data were collected from the Pacific Exchange Rate Service. Because of the advent of the Euro, the German Mark only continues until the end of 1998 and then we have data for the Euro from near the beginning of 1999 until March of 2003.

\section{THE RESULTS}

The trading strategy employed is simply to buy (go long) any futures contract that is below today's spot price and sell (go short) any contract that is above today's spot price. As discussed above we are assuming that the spot price is the best predictor of what the future spot price will be. Table 1 shows some summary statistics. Panel A shows the statistics for each currency including the total number of trades, the number of long trades and the number of short trades. It also shows the average return per trade and the cumulative return for each currency. For the entire data set there are 780 trades, 372 long trades and 408 short trades. The average return per trade is 1.52\% and the average long trade earns $1.30 \%$ and the average short trade earns $1.71 \%$. If a speculator had invested in every trade their cumulative return over the 13.25 years would have been $1183.89 \%$. It is worth noting that every currency had a positive average return per trade and, with the exception of the Swiss Franc, each currency had an average return that is positive for both long and short trades. The Swiss Fran had a negative average return per trade of $0.08 \%$ for its 33 short trades, although the long trades had an average trade of positive $1.15 \%$.

Panel B of Table 1 shows the percentage of winning trades for each currency. On average $63.2 \%$ of all trades are winners. Sixty and eight-tenths percent of long trades have positive returns and $65.4 \%$ of short trades have positive returns. All three of these numbers are significantly different than $50 \%$ with a p-value less than .05 . Each currency has greater than $50 \%$ incidence of positive returns. 
Table 1: Summary Statistics By Currency

\begin{tabular}{|c|c|c|c|c|c|c|c|c|}
\hline \multicolumn{9}{|c|}{ Panel A: Average and Cumulative Returns } \\
\hline Currency & Return & Long & $\mathbf{N}$ & Short & $\mathbf{N}$ & Total & $\mathbf{N}$ & time period \\
\hline AUD & $\begin{array}{c}\text { ave ret/trade } \\
\text { cum } \% \text { ret }\end{array}$ & $\begin{array}{r}1.90 \\
83.61 \\
\end{array}$ & 44 & $\begin{array}{c}3.75 \\
59.98 \\
\end{array}$ & 16 & $\begin{array}{c}2.39 \\
143.59 \\
\end{array}$ & 50 & $1 / 91-6 / 03$ \\
\hline CAD & $\begin{array}{c}\text { ave ret/trade } \\
\text { cum } \% \text { ret }\end{array}$ & $\begin{array}{c}0.78 \\
93.62 \\
\end{array}$ & 120 & $\begin{array}{c}2.29 \\
196.87 \\
\end{array}$ & 86 & $\begin{array}{c}1.41 \\
290.49 \\
\end{array}$ & 206 & $1 / 90-6 / 03$ \\
\hline SF & $\begin{array}{c}\text { ave ret/trade } \\
\text { cum } \% \text { ret }\end{array}$ & $\begin{array}{l}-0.08 \\
-2.79 \\
\end{array}$ & 33 & $\begin{array}{c}1.15 \\
95.08\end{array}$ & 83 & $\begin{array}{c}0.80 \\
92.29\end{array}$ & 116 & $1 / 90-6 / 03$ \\
\hline Pound & $\begin{array}{l}\text { ave ret/trade } \\
\text { cum } \% \text { ret }\end{array}$ & $\begin{array}{c}0.63 \\
52.44\end{array}$ & 83 & $\begin{array}{c}1.83 \\
29.25\end{array}$ & 16 & $\begin{array}{c}0.83 \\
81.68\end{array}$ & 99 & $1 / 90-6 / 03$ \\
\hline Yen & $\begin{array}{c}\text { ave ret/trade } \\
\text { cum } \% \text { ret }\end{array}$ & $\begin{array}{r}3.78 \\
113.54 \\
\end{array}$ & 30 & $\begin{array}{c}0.98 \\
128.45 \\
\end{array}$ & 131 & $\begin{array}{c}1.50 \\
241.98 \\
\end{array}$ & 161 & $1 / 90-6 / 03$ \\
\hline DM & $\begin{array}{c}\text { ave ret/trade } \\
\text { cum } \% \text { ret }\end{array}$ & $\begin{array}{c}1.55 \\
71.25\end{array}$ & 46 & $\begin{array}{c}1.36 \\
77.71\end{array}$ & 57 & $\begin{array}{c}1.45 \\
148.96\end{array}$ & 103 & $1 / 90-10 / 98$ \\
\hline Euro & $\begin{array}{c}\text { ave ret/trade } \\
\text { cum } \% \text { ret }\end{array}$ & $\begin{array}{c}4.54 \\
72.72 \\
\end{array}$ & 16 & $\begin{array}{c}5.90 \\
112.18 \\
\end{array}$ & 19 & $\begin{array}{c}5.28 \\
184.90 \\
\end{array}$ & 35 & $4 / 99-6 / 03$ \\
\hline All trades & $\begin{array}{c}\text { ave ret/trade } \\
\text { cum } \% \text { ret }\end{array}$ & $\begin{array}{r}1.30 \\
484.78 \\
\end{array}$ & 372 & $\begin{array}{c}1.71 \\
699.51 \\
\end{array}$ & 408 & $\begin{array}{c}1.52 \\
1183.89 \\
\end{array}$ & 780 & $1 / 90-6 / 03$ \\
\hline \multicolumn{9}{|c|}{ Panel B: Percentage Of Winning Trades } \\
\hline Currency & Long & & & Short & wins/all & Total & wins/all & time period \\
\hline AUD & $63.6 \%$ & & & $68.8 \%$ & $11 / 16$ & $65.6 \% *$ & $39 / 60$ & $1 / 91-6 / 03$ \\
\hline CAD & $57.5 \%$ & & & $79.1 \% *$ & $66 / 86$ & $66.5 \% *$ & $137 / 206$ & $1 / 90-6 / 03$ \\
\hline SF & $51.5 \%$ & & & $59.0 \%$ & $49 / 83$ & $56.9 \%$ & $66 / 116$ & $1 / 90-6 / 03$ \\
\hline Pound & $59.0 \%$ & & & $75.0 \% *$ & $12 / 16$ & $61.6 \% *$ & $61 / 99$ & $1 / 90-6 / 03$ \\
\hline Yen & $73.3 \% *$ & & & $56.5 \%$ & $74 / 131$ & $59.6 \% *$ & $96 / 161$ & $1 / 90-6 / 03$ \\
\hline DM & $63.0 \%$ & & & $66.7 \% *$ & $38 / 57$ & $65.0 \% *$ & $67 / 103$ & $1 / 90-10 / 98$ \\
\hline Euro & $75.0 \% *$ & & & $78.9 \% *$ & $15 / 19$ & $77.1 \% *$ & $27 / 35$ & $4 / 99-6 / 03$ \\
\hline All trades & $60.8 \% *$ & & & $65.4 \% *$ & $267 / 408$ & $63.2 \% *$ & $493 / 780$ & $1 / 90-6 / 03$ \\
\hline
\end{tabular}

Table 2 shows the average premium or discount of the futures price in relation to the spot price at the time of the trade. In panel A these statistics are shown by length of futures contract. Recall that in our simple strategy we trade in all of the futures contracts that are available at the beginning of each quarter. For some currencies only three month contracts are available. For other currencies there are also six, nine, twelve and fifteen month contracts. Panel A shows that the average discount or premium tends to increase as the length of the contract increases. (The 15 month contracts do not increase but since the sample has only 8 observations it is difficult to draw any conclusions.) When the discounts or premiums are annualized, however, the numbers generally decrease as the length of contract increases. The average return per trade is smallest in an absolute sense for the three month contract at $0.928 \%$, but when the returns are annualized the three month contract has a return of $3.764 \%$ which is the largest return.

In panel B of Table 2 the average premium or discount is shown for each currency. These numbers range from a low of $0.412 \%$ for the Canadian Dollar to $0.824 \%$ for the Japanese Yen.

The trading strategy we employ assumes that the spot price is a better predictor of the future spot price than is the futures price. This implies that the larger the discount or premium, the larger the expected profit from the strategy. For example, if the futures price is 5\% above today's spot price we stand to earn $5 \%$ if the futures price eventually falls to the level of today's spot price. To test this we can regress the absolute value of the discount or premium on the profit made per trade using the following regression:

$\%$ profit per trade $=\square+\square$ (absolute value of discount or premium) 
If the profit per trade is indeed associated with the discount or premium we would expect the slope coefficient to be significantly positive. The results of these regressions are shown in Table 3 . The results are shown for each contract length in each currency. Almost all of the slope coefficients are greater than zero as expected. Only the 6-moth Canadian Dollar and the 3-month and overall British Pound have negative values for the slope coefficient. For these three contracts the slope coefficient, however, is not statistically different from zero. For the individual currencies some of the slope coefficients are significantly greater than zero and some are not. For the overall sample the slope coefficients are significant with t-statistics of 2.447 for the 3-month contract, 2.570 for the 6-month contract, 2.015 for the 9-month contract, and 4.389 for all contracts combined. It is clear there is a statistically significant relationship between the profit and the level of the discount or premium when the entire data set is used. It is also worth mentioning that, even for the combined data set, the adjusted $\mathrm{R}$-squared numbers are quite low ranging from .016 to .023. This indicates that many other factors besides the discount or premium are important in explaining the profit per trade. In the next section simulations are performed to see if the strategy is profitable.

Table 2: Average Discount or Premium and \% Return

\begin{tabular}{|c|c|c|c|c|c|}
\hline \multicolumn{6}{|c|}{ Panel A: Results by Length of Trade } \\
\hline $\begin{array}{c}\text { Approx contract } \\
\text { length }\end{array}$ & $\mathbf{N}$ & $\begin{array}{l}\text { ave disc or prem } \\
\text { before trade }\end{array}$ & $\begin{array}{l}\text { Annualized disc or } \\
\text { prem before trade }\end{array}$ & $\begin{array}{l}\text { ave return per } \\
\text { trade after trade }\end{array}$ & $\begin{array}{c}\text { Annualized } \\
\text { return after trade }\end{array}$ \\
\hline 3 month & 311 & $0.571 \%$ & $2.304 \%$ & $0.928 \%$ & $3.764 \%$ \\
\hline 6 month & 256 & $1.158 \%$ & $2.327 \%$ & $1.730 \%$ & $3.490 \%$ \\
\hline 9 month & 140 & $1.800 \%$ & $2.407 \%$ & $2.391 \%$ & $3.201 \%$ \\
\hline 12 month & 66 & $1.868 \%$ & $1.868 \%$ & $1.486 \%$ & $1.486 \%$ \\
\hline 15 month & 7 & $0.993 \%$ & $0.794 \%$ & $2.784 \%$ & $2.221 \%$ \\
\hline all trades & 780 & $1.098 \%$ & $\mathrm{n} / \mathrm{a}$ & $1.518 \%$ & $\mathrm{n} / \mathrm{a}$ \\
\hline \multicolumn{6}{|c|}{ Panel B: Results for 3 Month Contracts by Currency } \\
\hline Currency & $\mathbf{N}$ & \begin{tabular}{|c|}
$\begin{array}{c}\text { Ave disc or prem } \\
\text { before trade }\end{array}$ \\
\end{tabular} & $\begin{array}{l}\text { Annualized disc or } \\
\text { prem before trade }\end{array}$ & $\begin{array}{c}\text { Ave return per } \\
\text { trade after trade }\end{array}$ & $\begin{array}{c}\text { Annualized } \\
\text { return after trade }\end{array}$ \\
\hline AUD & 48 & $0.431 \%$ & $1.735 \%$ & $1.077 \%$ & $4.378 \%$ \\
\hline CAD & 53 & $0.412 \%$ & $1.658 \%$ & $0.731 \%$ & $2.956 \%$ \\
\hline SF & 53 & $0.579 \%$ & $2.336 \%$ & $0.971 \%$ & $3.941 \%$ \\
\hline Pound & 52 & $0.523 \%$ & $2.108 \%$ & $0.837 \%$ & $3.390 \%$ \\
\hline Yen & 53 & $0.824 \%$ & $3.337 \%$ & $0.418 \%$ & $1.683 \%$ \\
\hline DM & 36 & $0.575 \%$ & $2.320 \%$ & $0.683 \%$ & $2.760 \%$ \\
\hline Euro & 16 & $0.798 \%$ & $3.230 \%$ & $0.353 \%$ & $1.419 \%$ \\
\hline All trades & 311 & $0.571 \%$ & $2.304 \%$ & $0.928 \%$ & $3.764 \%$ \\
\hline
\end{tabular}

\section{THE SIMULATIONS}

In this section results from various simulations are shown. Table 4 shows results from simulations performed on individual currencies. We assume an investor posts a $\$ 150,000$ cash margin and then trades $\$ 1$ million worth of contracts. This $15 \%$ margin is larger than required and is intended to minimize margin calls. At the beginning of each quarter the investor buys (goes long) the 90 day contract if the futures price is below the current spot price and visa versa. He then holds the contract until the Friday before the contract expires. He then leaves the proceeds of his trades in the account. At the beginning of the next quarter he may have more or less than the original $\$ 150,000$ but we assume he again trades $\$ 1$ million worth of contracts. Currently the exchanges require an initial margin of between $1.5 \%$ to $2.25 \%$ and a maintenance margin of between $1.1 \%$ and $1.7 \%$. Margin calls may occur if the account balance falls below the required maintenance margin. We assume that if a margin call does occur, the investor posts the required cash to continue with the strategy. We also assume fractional contracts can be purchased and that a transaction fee of $\$ 25$ per trade is required, which is higher than at some brokerage firms. We also ignore the interest that the investor could earn on the $\$ 150,000$ margin. Typically an investor could post a large percentage of the margin with T-Bills and earn interest. This means that the returns reported here are in excess of the T-Bill rate. 
Table 3: Regression results

\begin{tabular}{|lc|c|c|ccc|c|}
\hline \multicolumn{2}{|l|}{ \% profit per trade $=\square+\square$ ( \% discount or premium) } \\
\hline Currency & contract & $\mathbf{N}$ & adj R2 & Beta & t-stat & p-val & period \\
\hline AUD & 3 month & 48 & -0.012 & 1.380 & 0.680 & 0.500 & $1 / 91-6 / 03$ \\
& 6 month & 9 & & too & few & obs. & $1 / 91-6 / 03$ \\
& all & 60 & 0.056 & 3.131 & 2.114 & 0.039 & $1 / 91-6 / 03$ \\
\hline CAD & 3 month & 53 & -0.019 & 0.208 & 0.207 & 0.837 & $1 / 90-6 / 03$ \\
& 6 month & 52 & -0.020 & -0.016 & -0.019 & 0.985 & $1 / 90-6 / 03$ \\
& all & 206 & 0.002 & 0.365 & 1.161 & 0.247 & $1 / 90-6 / 03$ \\
\hline SF & 3 month & 53 & 0.016 & 2.779 & 1.360 & 0.180 & $1 / 90-6 / 03$ \\
& 6 month & 49 & 0.139 & 4.781 & 2.962 & 0.005 & $1 / 90-6 / 03$ \\
& all & 116 & 0.089 & 2.589 & 3.494 & 0.001 & $1 / 90-6 / 03$ \\
\hline Pound & 3 month & 52 & -0.018 & -0.356 & -0.306 & 0.761 & $1 / 90-6 / 03$ \\
& 6 month & 42 & -0.018 & 0.587 & 0.543 & 0.590 & $1 / 90-6 / 03$ \\
& all & 99 & -0.004 & -0.526 & -0.778 & 0.439 & $1 / 90-6 / 03$ \\
\hline Yen & 3 month & 53 & -0.013 & 0.719 & 0.584 & 0.562 & $1 / 90-6 / 03$ \\
& 6 month & 53 & -0.006 & 0.887 & 0.834 & 0.408 & $1 / 90-6 / 03$ \\
& all & 161 & 0.026 & 0.975 & 2.308 & 0.022 & $1 / 90-6 / 03$ \\
\hline DM & 3 month & 36 & -0.007 & 2.057 & 0.870 & 0.390 & $1 / 90-10 / 98$ \\
& 6 month & 36 & 0.013 & 2.305 & 1.210 & 0.235 & $1 / 90-10 / 98$ \\
& all & 103 & 0.011 & 1.021 & 1.472 & 0.144 & $1 / 90-10 / 98$ \\
\hline Euro & 3 month & 16 & 0.242 & 1.536 & 2.408 & 0.030 & $4 / 99-6 / 03$ \\
& 6 month & 15 & 0.118 & 1.360 & 1.696 & 0.114 & $4 / 99-6 / 03$ \\
& all & 35 & 0.166 & 1.580 & 2.783 & 0.009 & $4 / 99-6 / 03$ \\
\hline All & 3 month & 311 & 0.016 & 1.109 & 2.447 & 0.015 & $1 / 90-6 / 03$ \\
& 6 month & 256 & 0.022 & 1.235 & 2.570 & 0.011 & $1 / 90-6 / 03$ \\
& 9 month & 140 & 0.022 & 0.941 & 2.015 & 0.046 & $1 / 90-6 / 03$ \\
& all & 780 & 0.023 & 0.885 & 4.389 & 0.001 & $1 / 90-6 / 03$ \\
\hline
\end{tabular}

Table 4 shows the ending balance, the dollar profit, the total $\%$ profit, the annualized $\%$ profit, the number of years of trading, the high balance and the low balance for each currency. The most striking result is that for each currency the annualized profit is above 7\%. They range from a high of $47.71 \%$ for the Euro to $7.06 \%$ for the Japanese Yen. In two of the seven currencies, The Yen and the German Mark, there were margin calls. But even with the margin calls, if the investor had deep enough pockets to continue with the strategy, the overall annualized return was above $7 \%$.

Table 4: Simulation of 90 day contracts for each currency

\begin{tabular}{|l|c|c|c|c|c|c|c|c|}
\hline Currency & $\mathbf{N}$ & end bal & $\$$ profit & Total \% profit & annual \% profit & yrs & High Bal & Low Bal \\
\hline AUD & 48 & $\$ 665,600$ & $\$ 515,600$ & 343.73 & 12.93 & 12.25 & $\$ 665,600$ & $\$ 142,483$ \\
CAD & 53 & $\$ 536,199$ & $\$ 386,199$ & 257.47 & 10.09 & 13.25 & $\$ 610,116$ & $\$ 138,171$ \\
SF & 53 & $\$ 663,471$ & $\$ 513,471$ & 342.31 & 11.88 & 13.25 & $\$ 806,172$ & $\$ 66,167$ \\
Pound & 52 & $\$ 583,994$ & $\$ 433,994$ & 289.33 & 10.80 & 13.25 & $\$ 595,077$ & $\$ 150,000$ \\
Yen & 53 & $\$ 370,421$ & $\$ 220,421$ & 146.95 & 7.06 & 13.25 & $\$ 488,145$ & $-\$ 66,183$ \\
DM & 36 & $\$ 394,940$ & $\$ 244,940$ & 163.29 & 11.70 & 8.75 & $\$ 469,287$ & $-\$ 1,994$ \\
Euro & 16 & $\$ 714,105$ & $\$ 564,105$ & 376.07 & 47.71 & 4.00 & $\$ 714,105$ & $\$ 150,000$ \\
\hline Notes: Begin with $\$ 150,000$ margin but always invest in $\$ 1,000,000$ worth of currency per period. \\
All 7 make an annualized profit in excess of 7\%, and 6 of 7 earn in excess of 10\%. \\
A margin call occurs if the balance drops below \$30,000, i.e. 3\% of the 1 million invested. \\
In 2 of the 7 a margin call would have occurred during the time period.
\end{tabular}


Table 5 shows results of some simulations using all of the currencies. The first strategy is to create an equally-weighted portfolio of contracts. Again $\$ 150,000$ is posted as margin and $\$ 1$ million worth of contracts is purchased. An equal portion of the $\$ 1$ million is placed in the 90 day contract for each of 6 currencies. Before 1999 the German Mark is purchased as one of the six and after 1998 the Euro is purchased. This strategy yields an annualized profit of $1149 \%$ with $67.9 \%$ of the quarters showing a profit. The low balance was $\$ 123,729$ indicating that no margin call would have occurred since a balance of about $\$ 12,000$ is all that is required as a maintenance margin. The last two columns show a "worst case" scenario. It is possible that no margin calls occur in our simulation because the beginning point, January of 1990, happened to be a good time to begin the strategy. We determined the worst quarter to have begun the strategy and then calculated the lowest balance that would have occurred in the margin account. If trading had begun in January of 1995 the balance would have fallen to $\$ 87,771$ before increasing again. Even in these worst case scenarios no margin calls would have occurred.

The second line of Table 5 shows an equally-weighted strategy with a filter. All of the assumptions are the same as above with one exception. We chose to only invest in those contracts where the premium or discount of the futures contract in relation to the spot is above that currency's average premium or discount. We know from the regression analysis reported in Table 3 that larger premiums are associated with larger profit. So by eliminating the contracts with the lower premiums we should be able to increase profits. At the beginning of each quarter we look at all the discounts or premiums and invest an equal percentage of the $\$ 1$ million into those currencies with larger than average discounts or premiums. Occasionally, all 6 currencies meet the standard and are included. In four quarters there are no currencies that meet the standard so no trading is done. Usually, however, this procedure involves investing in 2-4 currencies. The annualized return from this strategy is $14.76 \%$ with $70.8 \%$ of the quarters yielding a positive return. The low balance was $\$ 150,000$. If this strategy had started in October of 1992 , the worst starting date for this strategy, the balance would have fallen to $\$ 33,190$ which is not low enough to initiate a margin call. Clearly restricting trades to only those with large discounts or premiums increases the profitability of the strategy. There is a $3.27 \%$ larger annual return using this strategy than the equally-weighted strategy without the filter.

The third line of Table 5 shows a "square dollar" strategy. All six currencies are quoted against the U.S. dollar so it is possible that any major move in the dollar could greatly affect all six currencies. In the square dollar strategy an attempt is made to minimize this risk. Half of the $\$ 1$ million is invested in long contracts and half in short contracts. In theory, if something dramatic happens to the dollar this strategy would minimize any ill effects of a large move in either direction. In 13 of the 53 quarters all of the contracts were either short or they were all long. In these 13 quarters no trading was done. This strategy yielded a 5.18\% return and $62.5 \%$ of the quarters had a profit. The low balance was $\$ 150,000$ and if trading had begun in January of 1998 , the worst case starting point, the balance would have gone as low as $\$ 70,493$. This strategy is presumably safer and the price paid for that safety is the lower annual return.

In the last line of Table 5 the final strategy was employed; a "square dollar" portfolio with an "easy" filter. Ideally, we would like to invest only in contracts where the discount or premium is larger than average for a currency and put half the money in a short position and half in a long position. Theoretically this should be a very safe and very profitable strategy. In reality, in the 53 quarters for which we have data, these conditions were met in only 6 quarters. The extreme level of non-trading greatly reduces the profits. We attempt to correct for the large amount of non-trading in the following manner. If no trading is called for, which was true in most quarters, the filter requirement is reduced. Instead of requiring a discount or premium to be larger than average, we simply select the largest premium or discount available in order to allow at least one short trade and one long trade. The annual return for this strategy is $6.38 \%$ and trading occurred in 40 of the 53 quarters. The low balance is $\$ 150,000$ and the worst case low balance is $\$ 104,945$. 
Table 5: Simulation of 90 day contracts for several overall strategies

\begin{tabular}{|c|c|c|c|c|c|c|c|c|c|c|}
\hline Strategy & $\mathbf{N}$ & end bal & \$ profit & $\begin{array}{c}\text { Total \% } \\
\text { profit }\end{array}$ & $\begin{array}{c}\text { Annual } \\
\% \text { profit }\end{array}$ & $\begin{array}{c}\text { \% trades } \\
\text { positive }\end{array}$ & High Bal & Low Bal & $\begin{array}{c}\text { worst case } \\
\text { low Bal }\end{array}$ & $\begin{array}{c}\text { Worst } \\
\text { start date }\end{array}$ \\
\hline $\begin{array}{c}\text { EW no } \\
\text { filter }\end{array}$ & 53 & $\$ 633,748$ & $\$ 483,748$ & 322.50 & 11.49 & 67.9 & $\$ 642,636$ & $\$ 123,729$ & $\$ 87,771$ & $1 / 95$ \\
\hline $\begin{array}{c}\text { EW with } \\
\text { filter }\end{array}$ & 48 & $\$ 924,291$ & $\$ 774,291$ & 516.19 & 14.76 & 70.8 & $\$ 924,291$ & $\$ 150,000$ & $\$ 33,190$ & $10 / 92$ \\
\hline $\begin{array}{c}\text { SQ no } \\
\text { filter }\end{array}$ & 40 & $\$ 292,974$ & $\$ 142,974$ & 95.32 & 5.18 & 62.5 & $\$ 351,814$ & $\$ 150,000$ & $\$ 70,493$ & $1 / 98$ \\
\hline $\begin{array}{c}\text { SQ easy } \\
\text { filter }\end{array}$ & 40 & $\$ 340,515$ & $\$ 190,515$ & 127.01 & 6.38 & 62.5 & $\$ 351,656$ & $\$ 150,000$ & $\$ 104,945$ & $4 / 98$ \\
\hline
\end{tabular}

EW no filter: Put $1 / 6$ of investment in each currency

EW with filter: Put equal portion of money in each currency that has a premium or discount above the currency average

SQ no filter: Put $1 / 2$ of the investment in short contracts and $1 / 2$ in long contracts.

SQ easy filter: If possible put $1 / 2$ in short contract where premium is above the currency average and $1 / 2$ in longs.

But if the filter eliminates a trade, then select the highest premium available to complete the square dollar investment.

Notes: Begin with $\$ 150,000$ margin but always invest in $\$ 1,000,000$ worth of currency

All 4 make an annualized profit in excess of $5 \%$.

A margin call occurs if the balance drops below $\$ 30,000$, i.e. $3 \%$ of the 1 million invested.

Restrictions on trading in the bottom three strategies result in some none-trading in some quarters.

From the simulation results we can draw several conclusions. First, all of strategies employed are profitable. Second, the strategies are not extremely risky. In none of the 5 strategies was there a margin call. Moreover, even if we had started each strategy at the worst possible time, a margin call would still not have occurred. Third, in general it is better to include contracts that have the largest discounts or premiums because they tend to yield the largest returns. This must be tempered, however, because extreme filters can lead to a large incidence of non-trading which eliminate many profit opportunities. Using a square dollar approach should theoretically be safer and reduce the chances for a margin call. This extra safety will be at the cost of a lower return. In our sample it is not clear that much safety is gained since the square dollar low balances are not significantly better than in the equally-weighted strategies.

\section{COMPARISON WITH THOMAS' RESULTS}

Thomas (1986) performs two simulations similar to those presented in our Table 5. In his first portfolio, he performs an equally-weighted simulation of all six of the currencies in his data set. He reports an annualized return of $13.3 \%$ for his 10 year period. Our equally-weighted portfolio yields an annualized return of $11.49 \%$ for 13.25 years, $1.18 \%$ less than the Thomas result. He also simulates a square dollar portfolio which has a return of $6.8 \%$ while ours has a return of $5.18 \%$ or $1.62 \%$ less. He reports that $58 \%$ of his individual trades were profitable while in our sample $63.2 \%$ of the trades are profitable. It appears that the results from both studies are somewhat similar but our results yield a slightly smaller return. It appears that the greater market efficiency in today's foreign exchange markets has not increased the profits of the strategy. Neither does it indicate that an earlier profitable strategy has since been "discovered" by the market and market participants have traded upon it causing it to disappear. It may be true that this strategy provides the investor or speculator a fair return given the level of risk that he assumes.

\section{CONCLUSION}

In this paper a trading strategy is employed that assumes that spot prices for foreign currencies follow a random walk. If true, the best predictor of the spot rate in the future is today's spot price and not today's futures contract price. The strategy indicated by this belief is to simply buy (go long) any futures contract that is below today's spot price and sell (go short) any contract that is above today's spot price. In effect, an investor should always trade as if the spot will end the period at today's spot rate and bet that movements toward the futures price 
will not occur. By following this strategy, $63.2 \%$ of the trades result in a profit. Various simulations that use this strategy all result in profits. In fact by posting a $15 \%$ margin, the strategies shown in Table 5 result in annualized returns from $5.18 \%$ to $14.76 \%$ and none results in a margin call. Other more elaborate strategies are clearly possible using the same basic random-walk notion. It is shown that the results found by Lee Thomas, from 1974-1984, have not appreciably diminished in more recent years.

\section{REFERENCES}

1. Alexander, S. S., 1961, "Price Movements in Speculative Markets: Trend or Random Walks", Industrial Management Review, Vol. 2, pp. 7-26.

2. Dooley, M. P. and J. Shafer, 1983, "Analysis of Short-Run Exchange Rate Behavior: March 1973 to November 1981", in Exchange Rate and Trade Instability: Causes, Consequences and Remedies, Ed. By D. Bigman and T. Taya, Cambridge, MA, Ballinger.

3. Hodrick, Robert J., 1987, The Empirical Evidence on the Efficiency of Forward and Futures Foreign Exchange Markets, Harwood Academic Publishers.

4. Thomas, Lee R., III, 1985, "A Winning Strategy for Currency-Futures Speculation", The Journal of Portfolio Management, Fall, pp. 65-69.

5. Thomas, Lee R., III, 1986, "Random Walk Profits in Currency Futures Trading", The Journal of Futures Markets, Vol. 6, No. 1, pp. 109-125.

6. Sweeney, R. J., 1986, "Beating the Foreign Exchange Market", Journal of Finance, 41, pp.163-82.

Notes 